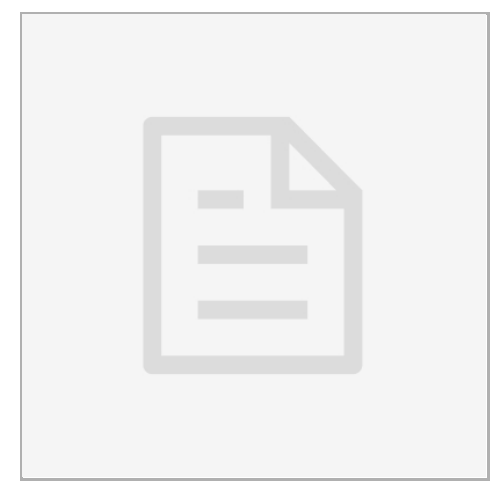

MAY 06, 2019

\section{(3) A simple, accurate, low cost method for starch quantification in green microalgae}

[ Botanical Studies

\section{Tze Ching Yong ${ }^{1}$, Chia-Sheng Chiu ${ }^{1}$, Ching-Nen Nathan Chen ${ }^{1}$}

\section{${ }^{1}$ National Sun Yat-Sen University}

Nathan Chen

National Sun Yat-Sen University

\section{open ठaccess}

\section{DOI:}

dx.doi.org/10.17504/protocol s.io. 2 mhgc 36

\section{External link:}

https://doi.org/10.1186/s405 29-019-0273-y

Protocol Citation: Tze Ching Yong, Chia-Sheng Chiu, ChingNen Nathan Chen 2019. A simple, accurate, low cost method for starch quantification in green microalgae. protocols.io https://dx.doi.org/10.17504/p rotocols. io. $2 \mathrm{mhgc} 36$

\section{MANUSCRIPT CITATION:} Yong TC, Chiu C, Chen CN, Optimization of a simple, accurate and low cost method for starch quantification in green microalgae. Botanical Studies doi: 10.1186/s40529-019-0273-y

License: This is an open access protocol distributed under the terms of the Creative Commons Attribution License, which permits unrestricted use, distribution, and reproduction in any medium, provided the original author and source are credited

\section{Protocol status: Working} We use this protocol and it's working 
Created: May 06, 2019

Last Modified: May 06,

2019

\section{PROTOCOL integer ID:}

22921

1 Harvest microalgal cells from $10 \mathrm{~mL}$ culture using swing bucket centrifugation ( $2600 \mathrm{~g}$ for $3 \mathrm{~min}$ ).

2 Transfer the cells to a 2-mL screw cap microtube. Spin briefly and get rid of the medium using a pippet. Freeze the cells immediately at $-15^{\circ} \mathrm{C}$ in an ice-crude sea salt mix.

3 Add $1 \mathrm{~mL}$ methanol/tetrahydrofuran mix $(\mathrm{v} / \mathrm{v}=1 / 3)$ to the cell pellet to extract pigments. Shake the microtube occasionally. Extract the pigments for at least $30 \mathrm{~min}$.

4 Centrifuge at $16,000 \mathrm{~g}$ at $4{ }^{\circ} \mathrm{C}$ for $10 \mathrm{~min}$. Discard the supernatant. Repeat the pigment extraction until the pellet becomes white, then dry the pellet at $65^{\circ} \mathrm{C}$ in an oven for one hour.

5 Wash the pellet out of the microtube repeatedly using $50 \mathrm{mM}, \mathrm{pH} 5$ sodium phosphate buffer, 5 $\mathrm{mL}$ in total, and transfer to a $15-\mathrm{mL}$ tube.

6 Autoclave the cell suspension at $134^{\circ} \mathrm{C}$ for one hour to disintegrate the starch granules.

7 Mix well and transfer $1 \mathrm{~mL}$ of the autoclaved sample to a 2-mL microtube, add $0.5 \mathrm{~g}$ acid-washed glass beads and then use a mini-beadbeater (BioSpec Products, USA) to smash the cells and release the starch (three cycles at the highest speed).

8 Transfer $0.5 \mathrm{~mL}$ of the beated sample to a microtube, add $0.5 \mathrm{~mL}$ sodium phosphate buffer (50 
$\mathrm{mM}, \mathrm{pH}$ ) and 2 units (in $20 \mu \mathrm{L}$ ) of glucoamylase ${ }^{(1)}$ for overnight digestion at $50^{\circ} \mathrm{C}$. Add the same amount of glucoamylase again the next morning for the second digestion in the same conditions for 7 hours.

9 After the double digestions, centrifuge the sample at 16,000 $\mathrm{g}$ at room temperature for $10 \mathrm{~min}$ and measure the glucose in the sample using the glucose assay protocol (the DNS method, see below).

\section{Glucose assay using the DNS method}

10 Build the standard curve for glucose assay: Prepare $10 \mathrm{mM}$ glucose solution in $50 \mathrm{mM}$ sodium phosphate buffer, $\mathrm{pH}$ 5.0, and do 2-fold serial dilutions until $312 \mu \mathrm{M}$ using the buffer.

11 Add $0.5 \mathrm{~mL}$ the glucose solution (or a sample) to $2 \mathrm{~mL}$ of the DNS reagent ${ }^{(2)}$ in a test tube (need to include 2 blanks to set zero). Mix well then heat the mixture in boiling water for $5 \mathrm{~min}$. Cool down in tap water and measure the $\mathrm{OD}_{540}$ of the glucose standards and the samples.

12 Build the standard curve of $\mathrm{OD}_{540}$ against glucose quantities. Use the regression equation to calculate the glucose quantities in the samples.

\section{Recipes and notes}

13 (1) Glucoamylase (TCI Chemicals, Tokyo, Japan; Cat. \# M0035) prep. : Take 100 units enzyme and dissolve it in $1 \mathrm{~mL}$ of $50 \mathrm{mM}$ sodium phosphate buffer, $\mathrm{pH} 5$ (17 mg of the enzyme powder contains about 100 units enzyme; the enzyme powder contains about 6000 units $/ \mathrm{g}$ ). This enzyme prep is good for 2 weeks if stored at $4{ }^{\circ} \mathrm{C}$. Unit definition: amount of protein to cause degadation of $10 \mathrm{mg}$ starch to glucose in $30 \mathrm{~min}$ (in specified conditions).

14 (2) DNS reagent prep: Dissolve $2 \mathrm{~g} \mathrm{NaOH}$ in $70 \mathrm{~mL} \mathrm{H}_{2} \mathrm{O}$, add $1 \mathrm{~g}$ of 3,5-dinitrosalicylic acid (DNS), then add $30 \mathrm{~g}$ potassium sodium tartrate. When the all chemicals are dissolved (takes about 2 - 3 days using sonication occasionally), bring the final volume to $100 \mathrm{~mL}$. The final concentrations of the chemicals: $0.5 \mathrm{M} \mathrm{NaOH}, 44 \mathrm{mM}$ dinitrosalicylicacid, $1 \mathrm{M}$ potassium sodium tartrate.

15 (3) This protocol is based on the manuscript "Optimization of starch quantificationin green microalgae: a simple, accurate, low cost method using glucoamylase and dinitrosalicylic acid" 
submitted to PLOS ONE. 